\title{
Non-venereal sclerosing lymphangitis of the penis: A report of two cases
}

Penisin non-veneryal sklerozan lenfanjiti: Iki olgu sunumu

Ersoy Acer, Mustafa Karabıçak*

Ahi Evran University Faculty of Medicine Training and Research Hospital, Department of Dermatology, Kırșehir, Turkey

* Tepecik Training and Research Hospital, Clinic of Urology, Izmir, Turkey

\begin{abstract}
Non-venereal sclerosing lymphangitis (NVSL) is a rare disease that develops after vigorous sexual intercourse. The disease was first described in 1923 by Hoffman. The condition is observed usually in the second or third decade of life. NVSL is characterized by a rope-like hard swelling around the coronal sulcus of the penis. It is generally painless and benign and usually resolves spontaneously. Penile Mondor's disease (PMD) must be considered in differential diagnosis. The lesion is harder and adherent to the underlying skin in PMD. Patients often have pain. Venous Doppler ultrasound is normal in NVSL but increased echogenicity and incompressible veins are observed in PMD. Here, we report two cases of NVSL. Establishing the diagnosis and knowing the course of the disease by dermatologists and urologists is very important to avoid misdiagnosis, unnecessary laboratory examinations and treatment.
\end{abstract}

Keywords: Lymphangitis, penis, sexual intercourse

Öz

Non-veneryal sklerozan lenfanjit (NVSL) sert cinsel ilişki sonrası ortaya çıkan, nadir görülen bir hastalıktır. Hastalık ilk olarak 1923 ylında Hoffman tarafından tanımlanmıştır. Genellikle 2. ve 3. dekatta görülür. Penisin koronal siklusu etrafında ip benzeri sert şişlik ile karakterizedir. Selim seyirli olup genellikle kendiliğinden geriler. Ağrı genellikle olmaz. Ayrıcı tanıda Penil Mondor hastalığı (PMH) mutlaka akla gelmelidir. PMH'de lezyon NVSL'ye göre daha serttir ve üstteki dokuya yapışıktır. Hastalarda ağıı sıklıkla olur. NVSL'de venöz Doppler ultrason normaldir ancak PMH'de artmış ekojeniteli ve sıkışııılamayan venler izlenir. Burada NVSL tanısı konulan iki olgu sunulmaktadır. Bu hastalığın dermatoloji ve üroloji hekimleri tarafından tanınması ve seyrinin bilinmesi yanlış tanı, gereksiz tetkik ve tedaviden kaçınmak için çok önemlidir.

Anahtar Kelimeler: Lenfanjit, penis, cinsel ilişki

\section{Introduction}

Non-venereal sclerosing lymphangitis (NVSL) is a rare, sudden disease that develops after a vigorous sexual intercourse. It occurs as a result of traumatic obstruction of the lymphatic vessels which settle in the coronal sulcus of the penis.

\section{Case Report}

\section{Case 1}

A 40-year-old male patient was admitted to our clinic with painless, hard swelling of the penis with a duration of 3 days. The patient's history revealed vigorous sexual intercourse 5

\footnotetext{
Address for Correspondence/Yazışma Adresi: Ersoy Acer MD, Eskişehir Osmangazi University Faculty of Medicine, Department of Skin and Venereal Diseases, Eskişehir, Turkey Phone.: +90 5067147574 E-mail: ersoyacer@hotmail.com ORCID-ID: orcid.org/0000-0002-6041-6636 Received/Geliş Tarihi: 09.01.2016 Accepted/Kabul Tarihi: 23.11.2016

Copyright 2017 by Turkish Society of Dermatology and Venereology

Turkderm-Turkish Archives of Dermatology and Venereology published by Galenos Yayınevi.
} 
days ago. On physical examination, firm, skin-colored, cord-like swelling which was non-tender on palpation was observed in dorsal coronal sulcus of the penis (Figure 1). There was no inguinal lymphadenopathy.

\section{Case 2}

A 33-year-old male patient was referred to our clinic with hard and slightly painful swelling of the penis which he noticed one day before. He gave a history of sexual intercourse about 1 week ago. On physical examination, cord-like, skin-colored swelling which was hard and a little painful on palpation was observed in the dorsal coronal sulcus of the penis (Figure 2). No inguinal lymphadenopathy was observed. None of the patients had a history of suspected sexual intercourse. The patients' medical history and systemic examinations were unremarkable. The patients had no history of drug use. The complete blood count, biochemical parameters, and urine tests were within the normal limits and HIV, hepatitis markers and rapid plasma reagent were negative. Penile Doppler ultrasound was also normal. Both patients were diagnosed with NVSL based on the clinical and laboratory findings. We administered systemic nonsteroidal anti-inflammatory treatment and advised the patients to abstain from sexual activity for a while. The lesions disappeared after 3 weeks.

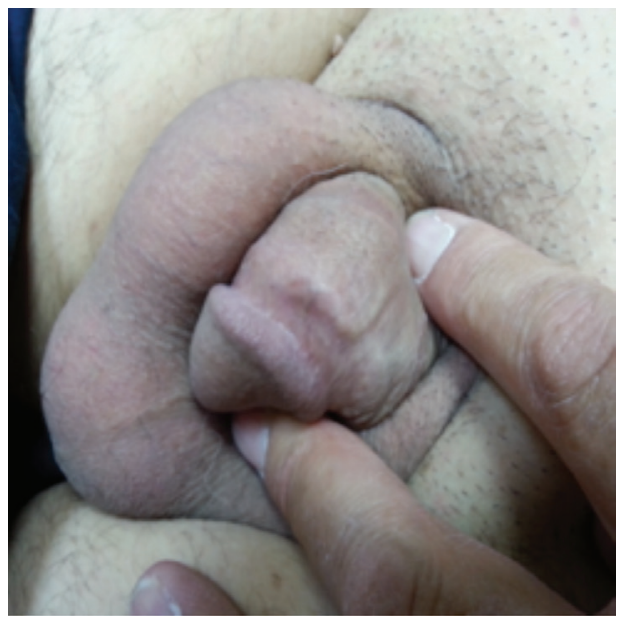

Figure 1. On palpation painless, hard, skin-colored cord like swelling in dorsal coronal sulcus of penis (Case 1)

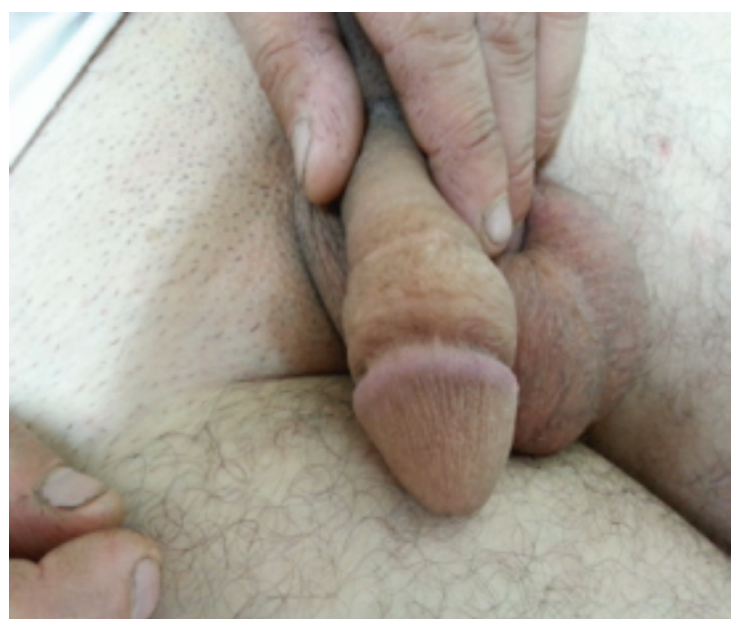

Figure 2. On palpation slightly painful, skin-colored swelling in dorsal coronal sulcus of penis (Case 2 )

\section{Discussion}

NVSL is clinically characterized by suddenly emerged rope-like hard swelling around the coronal sulcus of penis. It was first described in 1923 by Hoffman ${ }^{1}$ and was considered simulation of primary syphilis by gonorrheal lymphangitis (gonorrheal pseudo chancre). Later in 1938, Hoffman reported no relationship with venereal disease and called this condition as edematous non-veneral plastic lymphangitis of the coronary sulcus of the penis. Cases reported in subsequent years were called NVSL of the penis ${ }^{1,2}$. It develops within 1 week after hard sexual intercourse or masturbation. Therefore, it has been related to microtrauma after intense sexual activity ${ }^{3,4}$

It sometimes may be painful with erection, but it usually causes-little discomfort and resolves spontaneously ${ }^{4,5}$. Therefore, patients often do not consult physicians, thus the condition is reported to be less common.

The etiology of NVSL is not fully illuminated. However, it is believed that microtraumas due to rough sexual intercourse caused by traumatic obstruction of a large lymphatic vessel and eventually disease develops ${ }^{6}$. It is not related with an infectious microorganism, however, cases associated with gonorrhea, non-specific urethritis and syphilis have been reported ${ }^{7}$. Penile Mondor's disease (PMD) must be considered in differential diagnosis. PMD is thrombophlebitis of the superficial dorsal vein of the penis. Trauma, excessive sexual activity, local or remote infection, venous obstruction secondary to bladder distention, pelvic tumor, and injection of drugs into the dorsal penile vein can predispose to the development of thrombophlebitis of the superficial dorsal vein of the penis. Dorsal penile vein thrombosis occurs in the disease and the lesion is harder than in NVSL and adherent to the underlying skin. The lesion often extends to the suprapubic area. Patients have throbbing and pain that can be episodic or constant ${ }^{4,8}$. Venous Doppler ultrasound is normal in NVSL, but increased echogenicity and incompressible veins are observed in PMD. Sclerosis and hypertrophy of the lymphatic vessels are observed in histopathology examination of NVSL, whereas obstruction of the lumen of the vein is observed in microscopic sections of $\mathrm{PMD}^{9,10}$.

NVSL is a benign disease and lesions regress spontaneously. Patients are recommended sexual abstinence for a few weeks and non-steroidal anti-inflammatory drugs are started in painful situations. ${ }^{11}$ Surgical resection may be required for persistent lesions ${ }^{12}$.

As a result, NVSL, which is a rare disease, can regress spontaneously. To diagnose the disease and knowing the course of disease by dermatologists and urologists is very important to avoid misdiagnosis, unnecessary laboratory examinations and treatment.

\section{Ethics}

Informed Consent: Consent form was filled out by all participants Peer-review: Externally peer-reviewed.

\section{Authorship Contributions}

Surgical and Medical Practices: E.A., M.K., Concept: E.A., M.K., Design: E.A., M.K., Data Collection or Processing: E.A., M.K., Analysis or Interpretation: E.A., M.K., Literature Search: E.A., Writing: E.A.

Conflict of Interest: No conflict of interest was declared by the authors.

Financial Disclosure: The authors declared that this study received no financial support. 


\section{References}

1. Hoffman E: Simulation of gonorrheal lymphangitis as primary syphilis (gonorrheal pseudochancre). Munchen Med Wschr 1923;70:1167-8.

2. Hoffman E: Limited and edematous nonveneral plastic lymphangitis in sulcus coronarius of penis. Derm Z 1938;78:24-7.

3. Cantalejo C, Fernandez-Crehuet JL, Marcos A, Rodriguez-Pichardo A, Camacho F: Nonvenereal sclerosing lymphangitis of the penis: presentation of a clinical case. Actas Dermosifiliogr 2005;96:395-7.

4. Babu AK, Krishnan P, Andezuth DD: Sclerosing lymphangitis of penis literature review and report of 2 cases. Dermatol Online J 2014;15;20.

5. Gharpuray MB, Tolat $\mathrm{SN}$ : Nonvenereal sclerosing lymphangitis of the penis. Cutis 1991;47:421-2.

6. Lassus A, Niemi KM, Valle SL, Kiistala U: Sclerosing lymphangitis of the penis. Br J Vener Dis 1972;48:545-8.

7. Rosen $\mathrm{T}$, Hwong $\mathrm{H}$ : Sclerosing lymphangitis of the penis. J Am Acad Dermatol 2003;49:916-8

8. Nazir SS, Khan M: Thrombosis of the dorsal vein of the penis (Mondor's Disease) A case report and review of the literature. Indian J Urol 2010;26:431-3.

9. Griger DT, Angelo TE, Grisier DB: Penile Mondor's disease in a 22-year-old man. J Am Osteopath Assoc 2001;101:235-7.

10. Al-Mwalad M, Loertzer $H$, Wicht A, Fornara P: Subcutaneous penile vein thrombosis (Penile Mondor's Disease): pathogenesis, diagnosis, and therapy. Urology 2006;67:586-8.

11. Turan H, Büyükkaya $R$, Uslu E, Kayıkçı MA: Nonvenereal Sclerosing Lymphangitis of the Penis: Scientific Letter. Turkiye Klinikleri J Dermatol 2012:22:97-9

12. Broaddus SB, Leadbetter GW: Surgical management of persistent, symptomatic nonvenereal sclerosing lymphangitis of the penis. J Urol 1982;127:987-8 